\title{
Evaluating Iranian Secondary School Course Books for Learning English in Light of Construction of a Global Identity
}

\author{
Majid Elahi Shirvan \\ University of Bojnord, Bojnord, Iran
}

\author{
Negin Maddah \\ University of Zanjan, Zanjan, Iran
}

\begin{abstract}
English language is no longer a language bound to the native speakers but used by almost all people in the world which creates a new identity for them co-existing with their ethnic and national identities. This new identity is called global identity which is the result of the socialization of individuals in the wide community of practice of English language. The purpose of the present study was to investigate to what extent the new course books for learning English at Iranian secondary schools entitled Prospect series contribute to Iranian English language learners' global identity. To do this, all the activities in the three books of this series were evaluated based on the proposed framework of global identity. The findings indicated that the activities in this series are not appropriate in terms of the construction of a global identity for Iranian English language learners. The development of appropriate activities to enable Iranian English language learners to socialize in the broad community of practice of English language is discussed.
\end{abstract}

Keywords: global identity, Prospect series, national identity, community of practice

\section{Introduction}

The construction of identity takes place in certain language interactions in which context plays a decisive role in this construction (Deckert \& Vickers, 2011). English language as the world lingua franca is used almost everywhere and by almost all people in the world. The people interacting in English language have different backgrounds in terms of their first language and culture which have shaped their local and national identities. However, socialization and communication via English language contributes to a new type of identity which is beyond their local or national identities. In other words, to be communicatively competent in English language, individuals construct a global identity which co-exists with their national and local identities. This global identity emerging out of globalization and the advance in social media necessitates the interaction of individuals with the vast community of practice of English language including participants from societies with different features including language interactions and cultural transfers (Xu, 2013). Thus, this ability of construction and co-construction of the global identity via the use of English language is expected to be practiced by learners via the tasks, activities, and materials developed for learning English language so that they can survive at a global zone where they acquire new types of skills and strategies of communication while maintaining their ethnic and national identities. Local materials for learning English are to play a more pivotal role for English language learners to construct this global identity. Recently, the new course books for learning

Majid Elahi Shirvan, doctor, Ph.D., English Language Department, University of Bojnord.

Negin Maddah, M.A., English Language Department, University of Zanjan. 
English at Iranian secondary schools have been published. Therefore, the purpose of the present study is to evaluate three books from the series of English for Schools entitled Prospect used for secondary school students in Iran in light of the construction of global identity. Thus, the criteria of the evaluation are the construction of global identity in language learners and investigates whether or not the activities, texts, and conversations in the mentioned course books can contribute to the Iranian English language learners' ability to construct a global identity via the use of English language.

\section{Identity Construction}

The concept of identity is a well known concept which has various definitions. But here we aim to discuss identity from society and language views (Deckert \& Vickers, 2011). It is worth mentioning that the concept of identity is different from self. However, these two terms are related to each other (Owens, 2006). We have experienced ourselves from the beginning of our lives, e.g., reflecting on our past experiences (Van Lier, 2004) which might be a representation of our self. In addition, we might identify ourselves as citizens in a particular country known as legal identity which shows something about who we are (Deckert \& Vickers, 2011). However, in this paper we consider identity related to the concept of performance (Austin, 1975; Briggs, 1988; Butler, 1997); that is, how identity is constructed through our performance. According to Schiffrin (1996), "social identity is locally situated; who we are is, at least partially, a product of where we are and who we are with" (p. 198). Thus, the construction of identity takes place in certain language interactions. Therefore, the dynamic characteristics of identity, its changing nature, and its relation to performance, render it dependent on the context of the construction (Deckert \& Vickers, 2011). Gallagher and Marcel (1999) explained that "in my various activities, I am different [identities] to many different social groups" (p. 19). Thus, identity is a multi-faceted concept, partly the projection of an individual's sense of self, which is co-constructed. The definition of co-construction here is the "joint construction of a form, interpretation, stance, action, activity, identity, institution, skill, ideology, emotion or other culturally meaningful reality” (Jacoby \& Ochs, 1995, p. 171).

\section{Globalization}

Globalization is a continuous process which has influenced all societies (Xu, 2013). A large number of scholars (e.g., Blommaert, 2010; Eriksen, 2007; Garrett, 2010; Mckay, 2002; Mckay \& Bokhorst-Heng, 2008; Mufwene, 2010; Schneider, 2011; Scholte, 2000) have investigated its possible meanings and results. Blommaert (2010) defined globalization as:

Shorthand for the intensified flows of capital, goods, people, images and discourses around the globe, driven by technological innovations mainly in the field of media and information and communication technology, and resulting in new patterns of global activity, community organization and culture. (p. 13)

Possible implications of globalization in the realms of English Language Teaching (ELT) materials and EFL teaching have been explored (e.g., Xu, 2013; Kramsch, 2014). However, it is essential to investigate how globalization would affect constructing the global identity in EFL students. Constructing global or international identity provides language learners with the ability to communicate effectively in English to cater their needs and improve their situation in the global community. The evaluation of EFL course books of secondary school students in Iran and discussing possible ways of constructing global identity were our aim in this paper. 


\section{Culture and Globalization}

The significance of being communicatively competent within the globalization process is intertwined with the concept of intercultural competence. This has been addressed in the works of a number of scholars (e.g., Byram, 1997; Byram \& Fleming, 1998; Bredella \& Delanoy, 1999; Burwitz-Melzer, 2001; Krumm \& Portmann-Tselikas, 1998; Roberts, 2001; Zarate, Gohard-Radenkovic, Lussier, \& Penz, 2004). Byram and Zarate (1997) recognized five influential saviors in intercultural communicative competence: knowledge of self and others; of interaction; individual and societal, skills to discover and interact, skills to interpret and relate critical culture awareness and political education, attitudes: relativising self and valuing others (Kramsch, 2013). Discussing Byram's model, Corbett (2003) asserted that the saviors or capacities in Byram's model are the indications of student's level of skill or intelligence to achieve the Kramsch "third place". A "third place" is a situation which provides the learner with the ability to understand and negotiate the home culture and the target culture. In other words, it is a position enabling learners to see themselves from both inside and outside (Kramsch, 1993).

In addition, discussing the role of culture, Kramsch (2013) explained that language learners acquire a better understanding of their own identity facing and interacting with others via the application of their intercultural competence. On one hand, learners' awareness of their own identity is rooted in their experiences of their socio, cultural, and historical background via the use of their L1. On the other hand, this awareness cannot be strengthened without learners' understanding of the others' point of view about them. In other words, to have a clear understanding of themselves, they should see themselves through the eyes of the others or in Kramsch's term: "It is only by understanding Versailles that I can understand the uniqueness of Babylon. In turn, Babylon helps me to understand the unique characteristics of my culture" (p. 61). It is noteworthy here that, in Holquist's (1990) term, construction of the cultural and personal identity is the result of learners' willingness to respond to others through interaction and dialogue not just encounter with others.

\section{The Construction of Global Identity}

Regarding the role of English as a lingua franca in the world and the significance of constructing the international identity in the era of globalization, discussing the ways to provide learners with global identity through tasks and activities in the classroom is valuable. From the perspective of nested ecosystems model of Bronfenbrenner $(1979,1993)$, the role of classroom as a microsystem, "a pattern of activities, roles, and interpersonal relations experienced by the developing person in a given face-to-face setting" (p. 15), the classroom atmosphere, learners' beliefs and motivation plus cognitive, linguistic and affective factors may influence language learning in a positive or negative way (Peng, 2012). In that, the activities in the classroom are supposed to provide students with the ethnography of communication so that they can practice the norms of English language in its community of practice. The community of practice framework (Lave \&Wenger, 1991; Wenger, 1999; Wenger, McDermott, \& Snyder, 2002) is in the center of language socialization paradigm (Watson-Gegeo, 2004). According to Ochs (1993) socialization is "a dynamic interactional process between participants in expert and novice roles who develop cognitively through their activity, thereby changing over interactional time" (Deckert \& Vickers, 2011, p. 71). That is, through socialization in the community of practice of English language, individuals exercise the legitimate peripheral participation which integrates English language communicative competence with the development of their social identity. Therefore, core and 
peripheral members interact with each other and the socialization process in the broad community of practice of English language develops. This legitimization process will encourage inexperienced peripheral members, English language learners in this case, to develop and achieve success in order to be core members, communicatively competent learners who are able to construct an international identity in this case (Deckert \& Vickers, 2011).

Thus, materials used in the classroom should target this global community of practice of English language and provide language learners with the opportunity to communicate with English speakers all over the world to be familiar with their norms and cultures. As a result, this can facilitate the process of socialization and the construction of a global or international identity on the part of English language learners.

\section{Framework of Global Identity via the Use of English Language}

To gain a better understanding of the definition of the global identity via learning English language, the features involved in this construction should be first defined.

Community of practice: The community of practice of English language encompasses all the people in the world who interact with each other in English for different purposes and reasons (Lave \& Wenger, 1991; Wenger, 1999; Wenger, McDermott, \& Snyder, 2002). This community is not limited to people of a specific country, the so called native speakers, or a social context. This community of practice is wider than the communities of any other language in the world. That is, English language, due to the growth of globalization, has reached the state of the world lingua franca in which all people around the world experience socialization at the global level via this language.

Socialization: Socialization involves the interaction between an expert and a novice (Deckert \& Vickers, 2011). When it comes to English language, learners of English language are playing the role of a novice who is supposed to learn the rules and norms of the wider community of practice of English language, where all people from different parts of the world interact with each other, so that they become communicatively competent.

Legitimate peripheral participation: To become communicatively competent in English language, learners are to experience legitimate peripheral participation (Deckert \& Vickers, 2011). That is, all these learners have their own first language, nationality, and cultural background. The moment they start using English language, they are legitimized to be a member of the wider community of practice of English language. This legitimization takes place via meticulous observation and ethnography of communication.

Ethnography of communication: Ethnography of communication involves the observation of rules and norms of the wider community of practice of English language, including the grammar, vocabulary, functions, pronunciation, semantics, pragmatics, and discourse (Deckert \& Vickers, 2011).

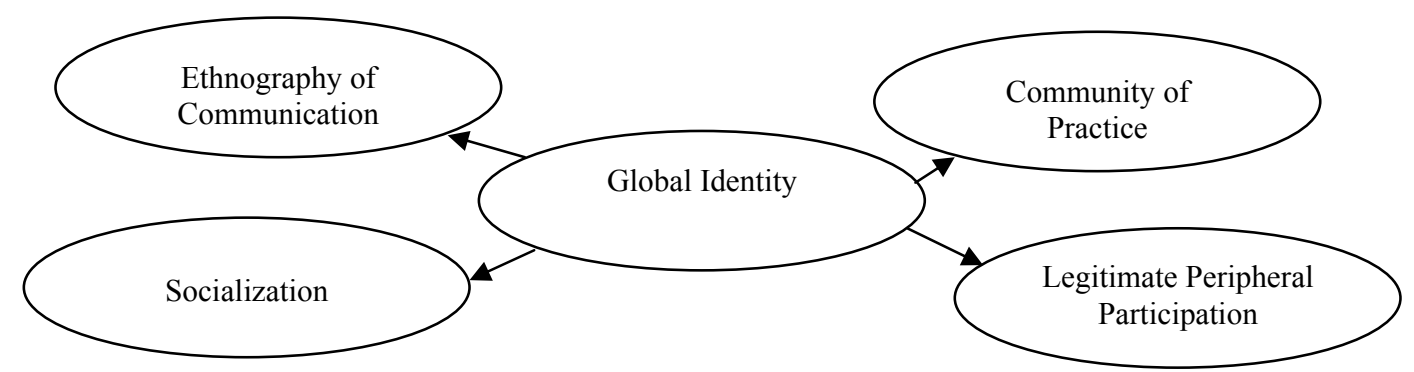

Figure 1. The proposed framework of global identity. 
Role of tasks and activities in the construction of global identities: Classroom activities can play a pivotal role in the construction of English language learners' global identity considering the elements mentioned in the framework since they provide these learners with ethnography of communication; that is, listening and reading activities in which learners learn how people from different parts of the world interact with each other using norms, rules, and functions which are not necessarily common but various due to the variety in the their backgrounds in terms of culture, first language, etc. Thus, English language learners can listen to or read conversations in which individuals from the wide community of practice of English language with different names, nationalities, accents, cultural backgrounds, eating habits, and greeting styles meet each other. In other words, they can construct their global identity by observing the rules, norms, styles, functions of the people from the wide community of practice of English language so that they can take advantage of them while meeting these members. Through listening and reading, they comprehend these norms and they become deeply aware of the dynamic nature of the co-construction of the global identity. On the other hand, there should be some activities for English language learners to practice socialization and legitimate peripheral participation by role playing the members of the community of practice to be communicatively competent while meeting them outside the context of classroom.

\section{Material}

For this paper, we have investigated the series of English books recently used in Iranian secondary schools. The books include the series of English for Schools entitled Prospect 1, 2, and 3. They were published by Iran's Textbooks Printing \& Publishing Company. The books which were evaluated in this article are the 2nd edition of Prospect 1 and 2 and the 1st edition of Prospect 3, published in 2015. English for Schools series include student book, teacher's guide, workbook, $\mathrm{CD}$, and flashcards for teachers. The books under investigation here are students' book of Prospect 1, 2, and 3. Each book includes conversations and activities for writing, speaking, and listening. Since Prospect is the first official book students use for learning English in public schools in Iran, the significance of developing activities for learners in order to make them communicatively and inter-culturally competent in the community of practice of English as a lingua franca and experience the process of socialization via legitimate participation seems necessary. All these are essential to construct learners' global identity.

Thus, in what follows we will evaluate the activities of the mentioned books based on the proposed framework of the construction of global identity.

\section{Data Analysis}

\section{The Evaluation of the Prospect Series Based on the Framework of the Construction Global Identity (Evaluation of Prospect 1)}

Introducing and names are the topics of the first two lessons in Prospect 1. Lesson one entitled My Name begins with a conversation indicating the first session of a class and a teacher introducing himself to the class and asking students to introduce themselves to the teacher. Besides, this lesson includes listening activities which have names common in Iran. Lesson two entitled My Classmates covers a conversation taking place at a school between two Iranian students and the activities of this lesson are almost the same as lesson one including names like Parham, Parisa, and Mr. Karimi, etc. As mentioned in the proposed framework of global identity, the significance of targeting the wide community of practice of English language to cater for the learners' 
ethnography of communication in classroom activities to construct the global identity is clear. Using common names and ways of greetings in Iran limits the community of practice of English language to a national level where these learners just communicate with their own countrymen in a Language which is not needed. In addition, in most sections of Prospect series Iranian names are ubiquitous and the contexts of conversations and reading sections are almost in Iran among Iranian people. In the following examples, you can see conversations and activities in lesson one and two of Prospect 1 with the Iranian names highlighted.

Lesson 1, Conversation (p. 6)

Teacher: Hi, class!

Students: Hello, Teacher.

Teacher: Thank you, sit down, please. I'm your English teacher. My name is Ahmad Karimi. Now, you tell me your names. What's your name?

Student 1: My name is Ali Mohammadi.

Teacher: How are you, Ali?

Student 1: Fine, thank you.

Teacher: And what's your name?

Student 2: My name is...

Lesson 2, Conversation (p. 10)

Ali: Who is that boy?

Parham: That's Erfan. He's our new classmate.

Ali: Let's talk to him.

Parham: Hi, Erfan. This is Ali.

Ali: Nice to meet you, Erfan.

Erfan: Nice to meet you, too.

Ali: Welcome to our school.

Erfan: Thank you.

Lesson 1, Practice 2 (Introducing Yourself, p. 7)

Listen to the examples. Then ask and answer with a classmate.

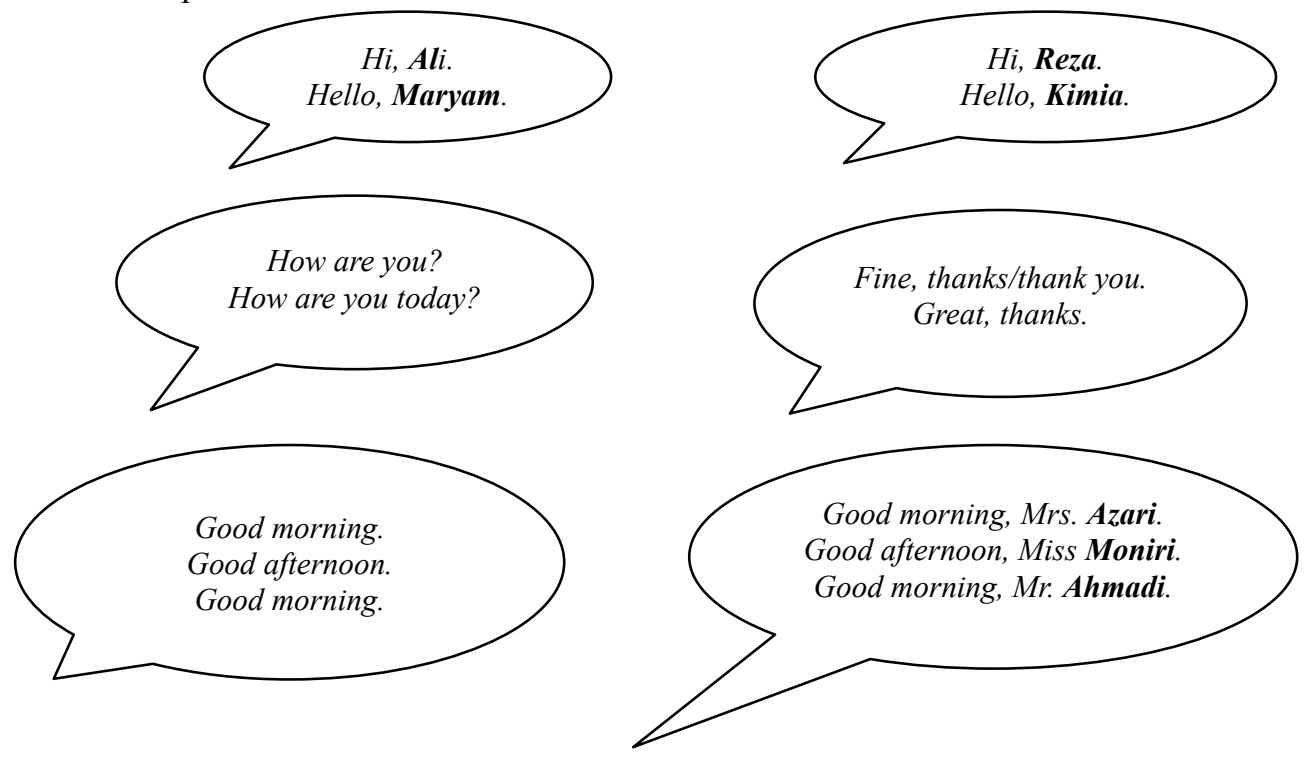




\section{Lesson 2, Practice 1 (Introducing Others, p. 11)}

Listen to the introductions and greetings.

This is my friend Parham.

This is my classmate Parisa.

This is my English teacher Mr. Kamali.

Nice to meet you.

Nice to meet you, too.

Another favorite topic in the wide community of practice of English language is the different kinds of foods and types of dressings of the individuals from different parts of the world. In lesson five of the PROSPECT 1, entitled My Appearance, clothes are introduced to learners. However, the focus of this lesson is totally on clothes common in Iran and it is in contrast with the features defined in the proposed framework to construct a global identity. An activity from lesson five in PROSPECT 1 including Iranian names and clothes is presented below.

Practice 2 (Talking About Appearance (Age, Clothes, and Color), p. 29)

Listen to the examples. Then ask and answer with a friend.

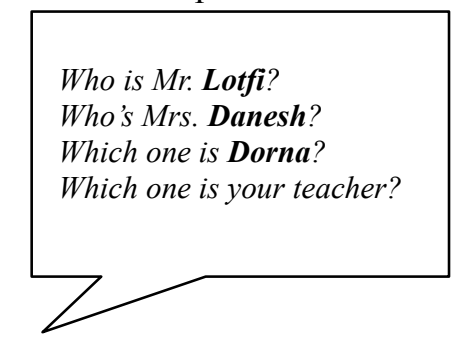

He's the old man. He's wearing a green jacket.

She's the old woman. She's wearing a brown manteau.

She's the young girl. She's wearing a gray scarf.

He's the young man. He's wearing a blue suit.

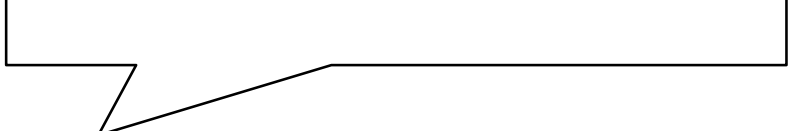

Furthermore, lesson five in Prospect 1 entitled My Favorite Food includes names of foods common in Iran. However, this topic is a good opportunity for the construction of a global identity by introducing different types of foods around the world in the wide community of practice of English language and help learners practice the process of socialization and legitimate peripheral participation to be communicatively competent in a community of practice of English language. In the following section, see one of the activities in lesson 8 with the foods common in Iran highlighted.

Practice 1 (Talking About Your Favorite Food and Drinks, p. 43)

Listen to the examples. Then ask and answer with a friend.

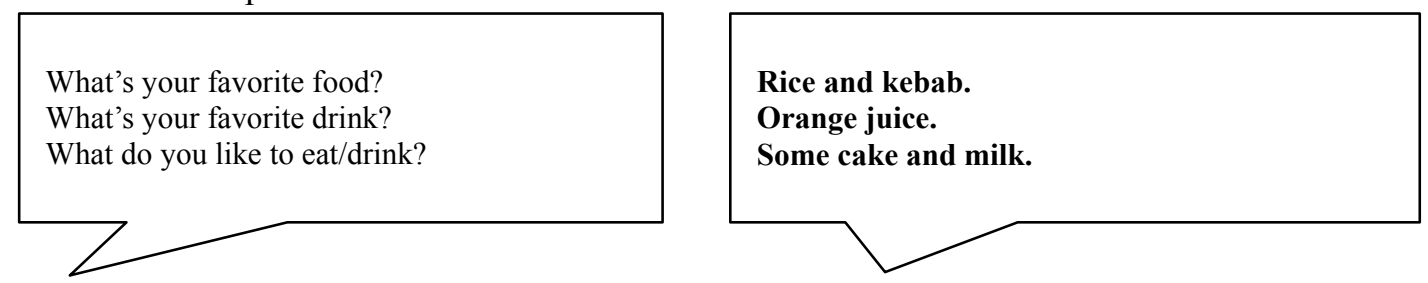

\section{The Evaluation of the Prospect Series Based on the Framework of the Construction Global Identity (Evaluation of Prospect 2 and 3)}

Continuing the evaluation of Prospect series, we will discuss those lessons of Prospect 2 and 3 which have topics more challenging in the construction of global identity. Lesson one in Prospect 2, entitled My Nationality, can provide learners with the information to learn different nationalities, their cultural background, and their norms, values and features. However, the information provided in this lesson is just limited to few 
nationalities which are not adequate considering the wide community of practice of English language. Some activities from lesson one in Prospect 2 are as follows.

Practice 3 (Talking About Nationalities (3), p. 14)

Listen to the examples. Then ask and answer with a friend.

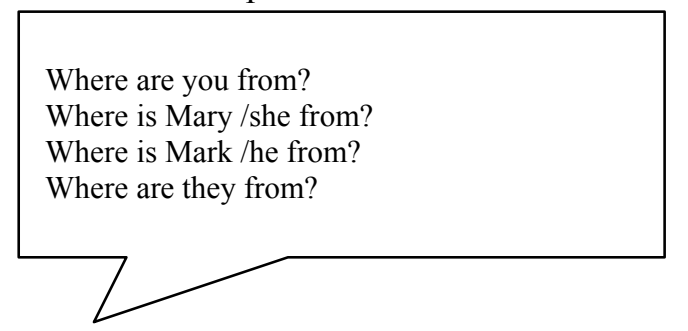

(I'm /we're from) Iran.

(She's from) England.

(He's from) France.

(They're from) Spain.

Role Play (p. 17)

\section{Group Work}

\section{Student A:}

Introduce one of your relatives/friends to your classmate.

Student B:

Greet your classmate and his/her guest.

Student C:

You are a guest from another country.

Lesson five of Prospect 2, entitled My City, begins with a conversation between Morteza and Phanindra talking about Esfahan, one of the cities in Iran. The scope of this conversation is just limited to the context of Iran which could have been extended to many other cities of the wide community of practice of English language. As mentioned earlier, being communicatively competent in the broad community of practice of English language by legitimate peripheral participation and being socialized in this community and exercising the application of its norms to shape the ethnography of communication in tasks can facilitate the construction global identity. When the activities in these books are limited to the norms and features of a narrower community of practice, there will be no opportunity for this construction. An example of activities of lesson five in Prospect 2 is presented below.

Practice 1 (Talking About a Place (1), p. 43)

Listen to the examples. Then ask and answer with a friend.

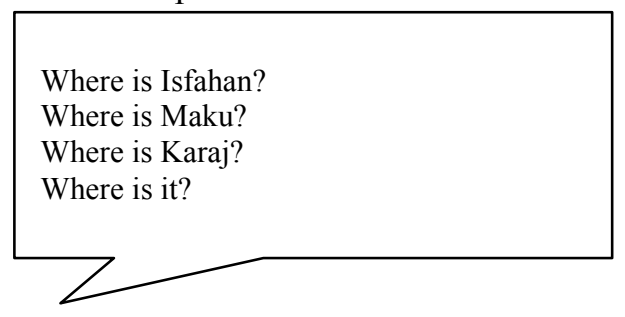

It's in the center of Iran. It's in the north-west. It's near the capital. It's in the south.

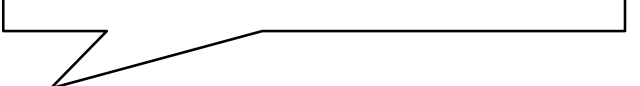

Prospect 3 is the last book in the series of English for Schools to be evaluated in this part based on the proposed framework of global identity construction. Lesson two in Prospect 3 entitled Travel begins with a conversation between a tourist from Germany and a recipient in a hotel in Tehran, Iran. In the following there is an example of the listening a listening activity from lesson two.

Practice 1 (Talking About Travel (1), p. 31)

Listen to the examples. Then ask and answer with a friend. 

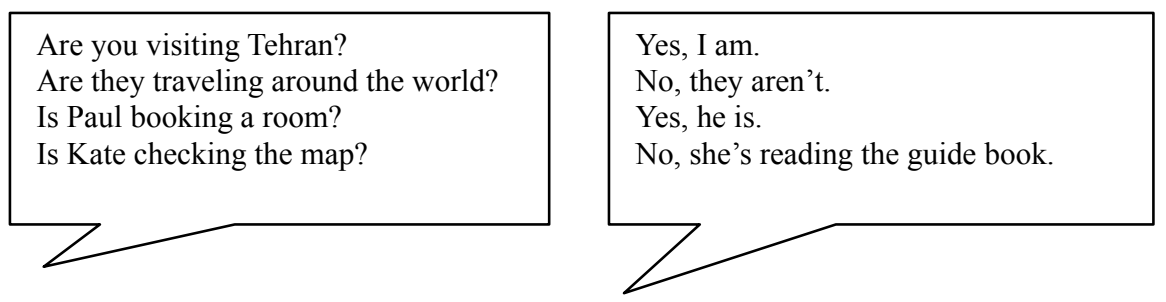

Names Paul and Kate and travelling around the world are good points but they are the only signs of the wide community of practice of English language around the world in this activity and in all the activities of this lesson. Familiarity with cities in Iran to travel is good but it is not something significant to practice different norms of the broad community of practice of English in the world and it is not practical to construct global identity by legitimate peripheral participation and socialization process.

Lesson three from Prospect 3 is about Festivals and Ceremonies. The lesson begins with the following conversation.

Listen to the conversation between two friends.

Elham: I just love New Year holidays!

Nasrin: Oh, yes, me too. It's really great.

Elham: We normally visit our relatives in Norooz. It's fun!

Nasrin: Do you get New Year gifts too?

Elham: Sure! We usually get money. I really like it.

Nasrin: Well..., we always go to my grandparents' houses.

Elham: That's nice! Does your grandmother cook the New

Year meal?

Nasrin: Actually, she doesn't. My mother makes it.

As seen in the example, the topic of this conversation between the two friends, native Iranians, is Norooz which is a national ceremony in Iran. Another activity from the same lesson is presented below.

Practice 1 (Talking About Festivals and Ceremonies (1), p. 51)

Listen to the examples. Then ask and answer with a friend.

Do you buy new clothes for the New Year?

Do you and your cousins set the Haft Seen table?

Do young children color the eggs?

Do Chinese people buy gold fish for the New Year?

Yes, I do.

No, we don't.

Yes, they usually color them.

No, they don't buy gold fish.
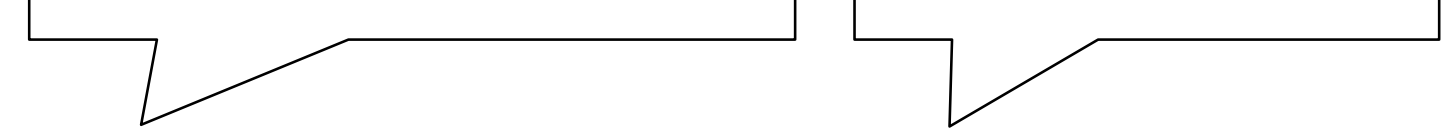

Practice 2 (Talking About Festivals and Ceremonies (2), p. 51)

Listen to the examples. Then ask and answer with a friend.

Does he recite the Holy Quran at the turn of the year?

Does your father give you New Year gifts?

Does she have many friends?

Does your mom make a special food for Norooz?
Yes, he does.

No, he doesn't.

Yes, she has many friends.

No, she doesn't make a special food.
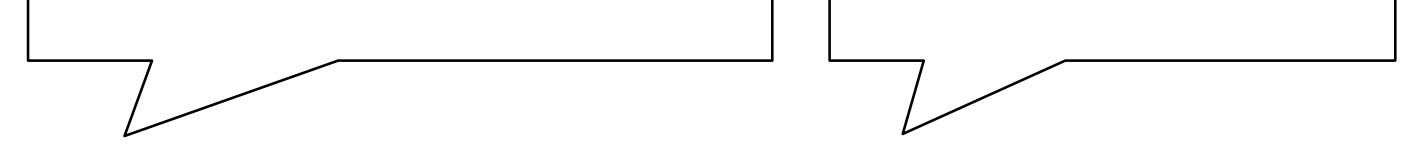
As indicated, the focus of the conversation and its activities is on Norooz which is a national ceremony in Iran. However, to construct a global identity, Iranian English language learners should be provided with conversations introducing festivals and ceremonies from the broad community of practice of English and to place learners in the position of novice learners to be legitimized by learning about other English users' cultural background and make them socialized by shaping their ethnography of communication.

\section{Discussion}

The evaluation of the activities in the three course books indicated that these books have not addressed enabling Iranian English language learners to construct a global identity. First of all, the broad community of practice of English language has not been the target of the developed activities for these course books; they are mainly limited to a narrower community of practice, which is the context of Iran. As a consequence, Iranian learners might not be able to socialize at the global level because they are not practicing legitimate peripheral participation via the activities of Prospect series. That is, they are not interacting with the core members, communicatively competent members with different nationalities. Therefore, one question might be raised here and that is "why should members of a particular community of practice, Iranian learners of English in this case, interact in a language which belongs to a wider community, English in this case, in their local community of practice, Iranian context in this case, where they can easily communicate in Persian?" Put it in simple terms, the use of English language in the national community of practice of Iranians is not a real need. A reflection on the principles of communicative language teaching reminds us of the fact that each communication is supposed to pivot on a real gap. Thus, the use English language in the activities addressing the Iranian community of practice whose members know each other in terms of names, greetings, culture, foods, clothing, etc., does not seem practical in terms of the development of Iranians' communicative competence in English language and the construction of their global identity. In addition, this might lead to a kind of identity discomfort in which the identities constructed, national versus international, might be at odds with each other. That is, the identity which is supposed to be constructed via the use of English language, its broad community of practice, is inappropriately pegged to an identity which is supposed to be constructed in a narrower community of practice by the use of Persian language. Secondly, closely related to the first issue, the activities in these course books do not provide Iranian English language learners with the appropriate ethnography of communication required for the construction of a global identity. The conversations and listening activities are bound to the context of Iran; thus, Iranian learners are not able to become familiar with the norms, rules, and function of communication within the community of practice of English language. In all, a fallacy in the definition of localization might have occurred in the development of the activities of these books and that is localization does not mean limiting the context of using English language to the national or local community of practice but it is the maintenance of the local or national identity within the global interactions through the use of English language. To do this purpose, Iranian English language learners should be able to present their Iranian identity while communicating in English language with the large number of members belonging to broad community of practice of English language. Therefore, activities in Prospect series or the supplementary materials for this series or the development of the other official course books for learning English in Iran are supposed to target the wider community of practice of English language so that Iranians can succeed in the "third place" of interactions with non Iranians while maintaining their national and local identities. 


\section{Conclusion}

The review of the concept of identity and globalization and the significance of constructing global identity with the help of improving learners' intercultural communicative competence inspired us to evaluate the series of books for secondary school students in Iran entitled Prospect based on constructing global identity. The criteria for this evaluation were the proposed framework for the construction of global identity. While, considering English as a lingua franca necessitates EFL learners to be able to communicate more easily with others in the world. The evaluation of the activities of the books indicated that they are totally developed based on the construction of a local identity which does not facilitate the process of socialization in the broad community of practice of English language.

\section{References}

Alavimoghadam, S. B., Kheirabadi, R., Foruzandeh Shahraki, E., Khadirsherbian, Sh., \& Nikupoor, J. (2015). English for schools. Prospect 1 (3rd ed.). Iran: Iran's Textbooks Printing \& Publishing Company.

Alavimoghadam, S. B., Kheirabadi, R., Foruzandeh Shahraki, E., Khadirsherbian, Sh., \& Nikupoor, J. (2015). English for schools. Prospect 2 (2nd ed.). Iran: Iran's Textbooks Printing \& Publishing Company.

Alavimoghadam, S. B., Kheirabadi, R., Foruzandeh Shahraki, E., Khadirsherbian, Sh., \& Nikupoor, J. (2015). English for schools. Prospect 3. Iran: Iran's Textbooks Printing \& Publishing Company.

Austin, J. L. (1975). How to do things with words (2nd ed.). Cambridge, MA: Harvard University Press.

Blommaert, J. (2010). The sociolinguistics of globalization. Cambridge: Cambridge University Press.

Briggs, C. L. (1988). Competence in performance: The creativity of tradition in Mexicano verbal art. Philadelphia: University of Pennsylvania Press.

Bredella, L., \& Delanoy, W. (Eds.). (1999). Interkultureller fremdsprachenunterricht. Tübingen: Narr.

Bronfenbrenner, U. (1979). The ecology of human development. Cambridge, MA: Harvard University Press.

Bronfenbrenner, U. (1993). The ecology of cognitive development: Research models and fugitive findings. In R. H. Wozniak and K. W. Fischer (Eds.), Development in context: Acting and thinking in specific environments (pp. 3-44). Hillsdale, NJ: Erlbaum.

Burwitz-Melzer, E. (2001). Teaching intercultural communicative competence through literature. In M. Byram, A. Nichols, and D. Stevens (Eds.), Developing intercultural competence in practice (pp. 29-43). Clevedon: Multilingual Matters.

Butler, J. (1997). Excitable speech: A politics of the performative. New York: Routledge.

Byram, M. (1997). Teaching and assessing intercultural communicative competence. Clevedon, UK: Multilingual Matters.

Byram, M., \& Fleming, M. (Eds.). (1998). Language learning in intercultural perspective. Cambridge: Cambridge University Press.

Byram, M., \& Zarate, G. (1997). Defining and assessing intercultural competence: Some principles and proposals for the European context. Language Teaching, 29, 14-18.

Corbett, J. (2003). An intercultural approach to English language teaching (Vol. 7). Clevedon, UK: Multilingual Matters.

Deckert, S. K., \& Vickers, C. H. (2011). An introduction to sociolinguistics: Society and identity. London, UK: A\&C Black.

Eriksen, T. H. (2007). Globalization: The key concepts. Oxford, New York: Berg.

Garrett, P. (2010). Meanings of "globalization": East and west. In N. Coupland (Ed.), The handbook of language and globalization (pp. 447-474). Maldden, Oxford, West Sussex: Wiley-Blackwell.

Gallagher, S., \& Marcel, A. J. (1999). The self in contextualized action. Journal of Consciousness Studies, 6(4), 4-30.

Holquist, M. (1990). Dialogism: Bakhtin and his world. London: Routledge.

Jacoby, S., \& Ochs, E. (1995). Co-construction: An introduction. Research on Language and Social Interaction, 28(3), $171-183$.

Kramsch, C. (1993). Context and culture in language teaching. Oxford University Press.

Kramsch, C. (2013). Culture in foreign language teaching. Iranian Journal of Language Teaching Research, 1(1), 57-78.

Kramsch, C. (2014). Teaching foreign languages in an era of globalization: Introduction. The Modern Language Journal, 98(1), 296-311.

Krumm, J., \& Portmann-Tselikas, P. (Eds.). (1998). Deutsch zwischen den Kulturen. Oesterreichische Beiträge zu Deutsch als Fremdsprache (German between cultures. Austrian contributions to German as a foreign language). Innsbruck/Wien: Studienverlag. 
Lave, J., \& Wenger, E. (1991). Situated learning: Legitimate peripheral participation. Cambridge: Cambridge University Press.

McKay, S. L. (2002). Teaching English as an international language: Rethinking goals and approaches. Oxford, New York: Oxford University Press.

McKay, S. L., \& Bokhorst-Heng, W. D. (2008). English in an era of globalization, international English in its sociolinguistic contexts: Towards a socially sensitive pedagogy (pp. 30-17). New York: Routledge.

Mufwene, S. S. (2010). Globalization, global English, and world English(es): Myths and facts. In N. Coupland (Ed.), The handbook of language and globalization (pp. 31-55). Maldden, Oxford, West Sussex: Wiley-Blackwell.

Ochs, E. (1993). Constructing social identity: A language socialization perspective. Research on Language and Social Interaction, 26(3), 287-306.

Owens, T. J. (2006). Self and identity. In Handbook of social psychology (pp. 205-232). US: Springer.

Peng, J. E. (2012). Towards an ecological understanding of willingness to communicate in EFL classrooms in China. System, 40(2), 203-213.

Roberts, C., Byram, M., Barro, A., Jordan, S., \& Street, B. (2001). Language learners as ethnographers. Clevedon: Multilingual Matters.

Schiffrin, D. (1996). Narrative as self-portrait: Sociolinguistic constructions of identity. Language in Society, 25(2), 167-203.

Schneider, E. W. (2011). English into Asia: From Singaporean ubiquity to Chinese learners' features. In M. Adams and A. Curzan (Eds.), Contours of English and English language studies (pp. 135-156). Ann Arbor: University of Michigan Press.

Scholte, J. A. (2000). Globalization: A critical introduction. Hampshire and New York: Palgrave Macmillan.

Van Lier, L. (2004). The ecology and semiotics of language learning: A sociocultural perspective. Educational Linguistics, 3 , 55-77.

Watson-Gegeo, K. A. (2004). Mind, language, and epistemology: Toward a language socialization paradigm for SLA. Modern Language Journal, 331-350.

Wenger, E. (1999). Communities of practice: Learning, meaning, and identity. Cambridge: Cambridge University Press.

Wenger, E., McDermott, R. A., \& Snyder, W. (2002). Cultivating communities of practice: A guide to managing knowledge. Harvard Business Press.

Xu, Z. (2013). Globalization, culture and ELT materials: A focus on China. Multilingual Education, 3(1), 1-19.

Zarate, G., Gohard-Radenkovic, A., Lussier, D., \& Penz, H. (2004). Cultural mediation in language learning and teaching. Strasbourg: Council of Europe. 